\title{
Towards An Open Access Policy Framework: A Case Study of COAR
}

\section{Bijan Kumar Roy}

Department of Library \& Information Science, The University of Burdwan, West Bengal, India

bijankumarroy@yahoo.co.in, orcid.org/0000-0001-9735-9586

\section{Subal Chandra Biswas}

Department of Library \& Information Science, The University of Burdwan, West Bengal, India

scbiswas 56@yahoo.co.in, orcid.org/0000-0002-6047-369X

\section{Parthasarathi Mukhopadhyay}

Department of Library \& Information Science, University of Kalyani, West Bengal, India

psmukhopadhyay@gmail.com, orcid.org/0000-0003-0717-9413

\begin{abstract}
This paper examines Open Access (OA) self archiving policies of different Open Access Repositories (OARs) affiliated to COAR (Confederation of Open Access Repositories) as partner institutes. The process of scrutiny includes three major activities - selection of databases to consult; comparison and evaluation of Open Access policies of repositories listed in the selected databases and attached to COAR group; and critical examination of available self archiving policies of these OA repositories against a set of selected criteria. The above steps lead to reporting the following results: key findings have been identified and highlighted; common practices have been analyzed in relation to the focus of this paper; and a best practice
\end{abstract}

This work is licensed under a Creative Commons Attribution 4.0 International License

Uopen Journals | http://liberquarterly.eu/ | DOI: 10.18352/lq.10227 
benchmark has been suggested for popularizing and strengthening OARs as national research systems. This paper may help administrators, funding agencies, policy makers and professional librarians in devising institutespecific self archiving policies for their own organizations.

Key Words: Open Access Policy Framework; Open Access Policies; Open Access Repository; Open Access Interoperability; COAR Repositories

\section{Introduction}

The Confederation of Open Access Repositories (COAR) is a dynamic, fastgrowing association of repository initiatives launched in October 2009 with around 60 members and partner organizations from 24 countries mainly from Europe, Latin America, Asia, and North America. It has currently a membership strength of over 100 institutions worldwide from 35 countries in 6 continents (as on December, 2017) representing universities, research institutions, government research funders, and others. The main objectives of COAR are to i) enhance the visibility of research outputs through OA repositories; ii) lobby for repositories, their networks, and repository-based e-Infrastructures at the national and international levels; iii) identify and promote strategies to fill repositories with content and facilitate agreements with publishers; iv) work closely with the repository community towards repository standardization and interoperability; and v) provide professional advice and networking opportunities for repository managers and practitioners. The mission of COAR is to enhance greater visibility and application of research outputs through global networks of Open Access digital repositories, based on international collaboration and interoperability. The COAR evolved out of a European project called the Digital Repository Infrastructure Vision for European Research (DRIVER) and progressed over time (2009-2017) with some major events listed in Table 1. The main objective of this paper is to analyze open access policies of different OARs of COAR member organizations and to propose best practice guidelines in line with global recommendations in order to strengthen national research systems.

\section{Literature Review}

There are many studies on OARs development covering specific geographical areas such as UK (Markland, 2006; Pinfield, 2003; van Westrienen 
Bijan Kumar Roy et al.

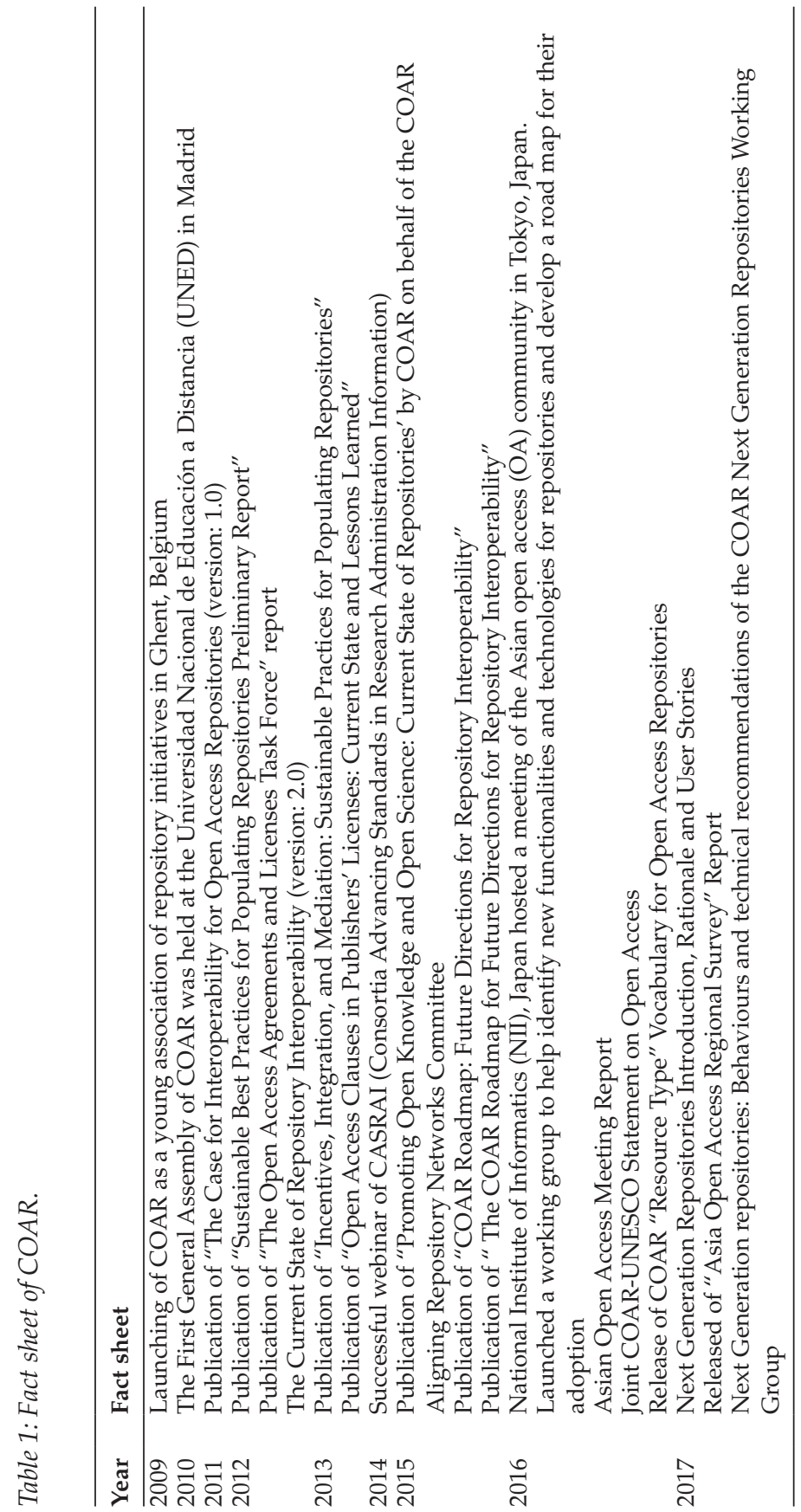


\& Lynch, 2005), Spain (Melero, Abadal, Abad, \& Rodríguez-Gairín, 2009); Italy (Gargiulo \& Cassella, 2010), Greece (Chantavaridou, 2009); Brazil (Dhanavandan \& Mary, 2015). During 2012-2016, Roy, Biswas and Mukhopadhyay $(2012 a, b, 2013,2015)$ have conducted several studies covering different aspects of OARs. In their recent research, they surveyed almost all the COPAI (Coalition of Open Access Policy Institutions) members OARs and compared their policy documentations against selected criteria such as archiving policy, deposit policies, metadata policies, preservation policies etc (Roy, Biswas, \& Mukhopadhyay, 2016). Another paper (Dhanavandan \& Tamizhchelvan, 2014) showed trends and development of institutional repositories (IR) in south Asian countries. In another study, (Dhanavandan \& Tamizhchelvan, 2015) reported the growth and development of OARs in BRICS Countries. Another group of authors (George, 2006; Markey, Rieh, St. Jean, Kim, \& Yakel, 2007) reported the development of IRs in the USA as a whole. Rieh, Markey, St. Jean, Yakel, and Kim (2007) reported that the majority of the research universities in the USA had implemented OARs for their own organization. Other researchers (Shreeves \& Cragin, 2008) reported that only $40 \%$ of the institutions that offered doctoral degrees in the USA had an IR.

But repositories all over the world are far behind from the expectations (in view of the exponential growth of OA repositories) when policy matters are concerned. Millington (2006) reported that about two thirds of OARs did not have publicly stated policies on the basis of his study on OpenDOAR ${ }^{1}$ database (http://www.opendoar.org/). The situation in relation to OA policy documentation is almost the same even after 12 years. There are 860 (as on June, 2017) policy proposals registered in ROARMAP² (Registry of Open Access Repository Mandates and Policies-http://roarmap.eprints.org/) database worldwide which covers only $26 \%$ of total OARs registered in OpenDOAR database (3346 OARs as of June, 2017). In this context, formulating OA self archiving policy documentation in line of the global recommendations and finalizing 'best practice' guidelines has become an essential task to the repository managers and many researchers (Armbruster, 2011; Asamoah-Hassan, 2010; Barton \& Waters, 2004; Rieh, St. Jean, Yakel, Markey, \& Kim, 2008; Shearer, 2005; Ware, 2004b) have advocated for devising OA self archiving policies to populating OARs globally. Interestingly, repositories included under the COAR group are showing a high-level of awareness in formulating OA policies, for example 51 members out of 81 listed members and partners in COAR are having their OA policy framework, i.e. a total of $62.96 \%$ members of COAR are OA policy compliant. On the other hand, these 
51 members of COAR amounts only to $6 \%$ in the global-scale (i.e. 51 COAR members out of $860 \mathrm{OA}$ policy compliant repositories all over the world; see Annex 1).

\section{Methodology for Analyzing Policy Documents}

At the first stage of our study, all COAR-member repositories (https:/ / www. coar-repositories.org) have been reviewed. In the second stage, only 51 repositories having OA self archiving policies (at least one policy mentioned in Table 2) have been short-listed for evaluation. It is to be noted that this study has considered only those repositories that are affiliated to COAR and having OA self archiving policies mentioned in OpenDOAR, ROAR ${ }^{3}$ or ROARMAP databases. Annex I provides OA self archiving policy information regarding all 51 repositories under study. This study, apart from comparing and analyzing policy proposals of COAR member institutions, also consulted other important sources like OpenDOAR, ROAR, SHERPA/RoMEO, SHERPA/ JULIET and SHERPA/FACT to improve the accuracy level of the results. The required datasets were extracted from these online databases (up to June, 2017) and were analyzed thereupon against pre-defined criteria (as listed in Table 2). The parameters as listed herewith in Table 2 are based on the recommendations given by many experts (Crow, 2002; Green, Macdonald, \& Rice, 2009; Jones, Andrew, \& MacColl, 2006; Swan, 2012; Swan, Gargouri, Hunt, \& Harnad, 2015). The major 9 policy elements (as consolidated in Table 2) cover all the basic activities related to open access repositories of any type or size.

Table 2: OA self archiving policies and related issues.

\begin{tabular}{|c|c|}
\hline Policy & Issues/Activities \\
\hline Version Archiving Policy & Mandatory or optional; time; form \& version \\
\hline Content Ingest Policy & Type of items; eligible contributors; deposition rules \\
\hline Advocacy and Promotion & Organization \& management; categories \& sub-categories; total \\
\hline Policy & $\begin{array}{l}\text { number of objects; frequency of deposition; level of awareness / } \\
\text { awareness \& marketing }\end{array}$ \\
\hline Copyright \& Licensing & Rights management; licensing pattern \\
\hline Policy & \\
\hline Data Access Policy & Access to items; access pattern; degree of openness \\
\hline Embargo Policy & Embargo period or retention period \\
\hline Standards Support Policy & Level of support; protocol used; eligible depositors; schema used \\
\hline Preservation Policy & File format; backup \\
\hline Withdrawal Policy & Reasons for withdrawal or removal \\
\hline
\end{tabular}




\section{Policy Elements of OARs: Analysis and Interpretation}

This section of the present study compares all 51 OARs in respect of archiving, contents type, number of objects, copyrights, data access policy, etc. covered in their policy documentations (Annex 1) in order to show the strength and weakness of the policy framework of OARs.

\subsection{Version Archiving Policy}

One of the major objectives of an open access repository is to support long term archiving of institution specific knowledge objects and thereby formulating an archive policy for any OAR is an important task for the repository developers. The major issues related to archiving centre around one basic question-what is to be deposited: the submitted manuscript, the accepted manuscript, or the published paper. It is found that a total of 36 repositories out of 51 repositories $(70.5 \%)$ have mentioned this policy. The majority of these 36

Fig. 1: Version archiving policy.

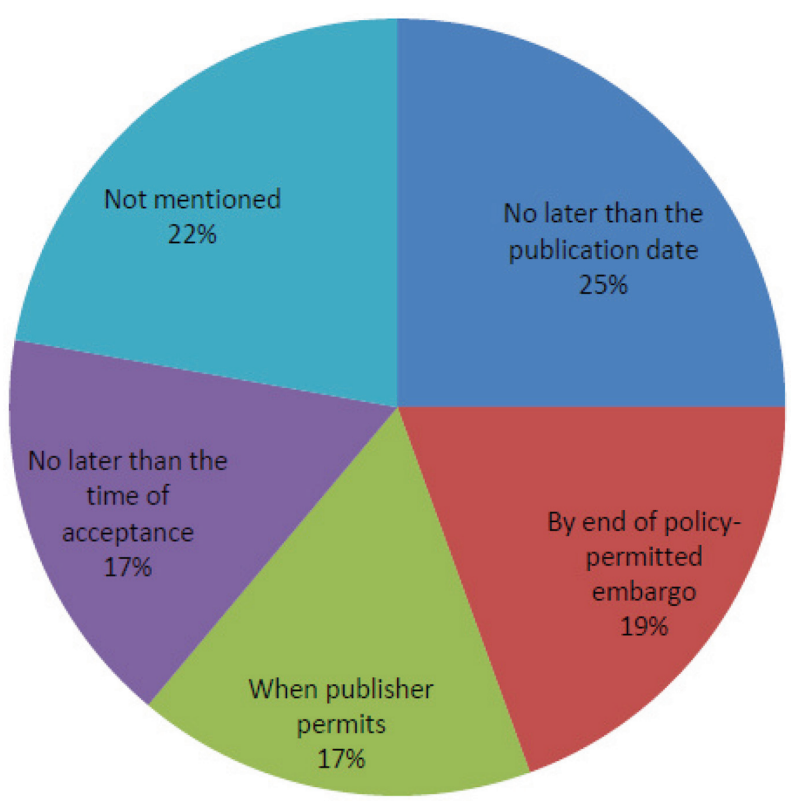


repositories (twenty-three (23) repositories) have recommended archiving an author's final peer-reviewed version immediately after acceptance of publication, whereas seven (7) repositories (out of 36 repositories that reported an archiving policy) have mentioned archiving the published edition (this is the version of record, the version finally published) and the rest of the repositories in these 36 repositories (nine (9) to be exact) support the deposition of any version 'no later than the publication date'. Nevertheless, Queensland University of Technology (sl. no. 1) and Joint Information Systems Committee (sl. no. 45) support as well the pre-print as the post-print version. It is interesting to note that there are differences among repositories with respect to the 'time-point of deposit' (Figure 1). For example, seven (7) repositories mention deposition of items 'by end of policy-permitted embargo' specified by the publishers, six (6) repositories suggest deposition of items 'when publisher permits' and another six (6) repositories recommend time-point of deposit as 'No later than the time of acceptance'.

\subsection{Content Ingest Policy}

This policy covers some relevant questions such as 'what will be the appropriate contents and what will be the Ingest policy'.

\subsubsection{Content Types}

There is no hard and fast rule regarding content type or what an IR should possess. Generally, repositories do not host not-textual objects like software, datasets, patents, research data, monographs, etc. (OpenDOAR, 2018; ROAR, 2018). It is found that the majority of the OARs cover journal articles, theses and dissertations; working papers; research reports, book chapters etc and Figure 2 lists the document types (OpenDOAR, 2018). There are 2374 (out of 3346 as of June, 2017) OARs that hold journal articles, which comprise $70 \%$ of the total productions, ranks 1 . While "Theses and dissertations" is the $2^{\text {nd }}$ most important and largest type (56.3\%) and "Books, chapters and sections" is the $3^{\text {rd }}$ largest type $(38.4 \%)$. There are mandates at national and international level for inclusion of Grey literature or non-textual objects in the OARs, but only a few repositories house these types of objects. It is therefore suggested that IRs should cover not only articles but also the datasets in more detail. 
Fig. 2: Content type.

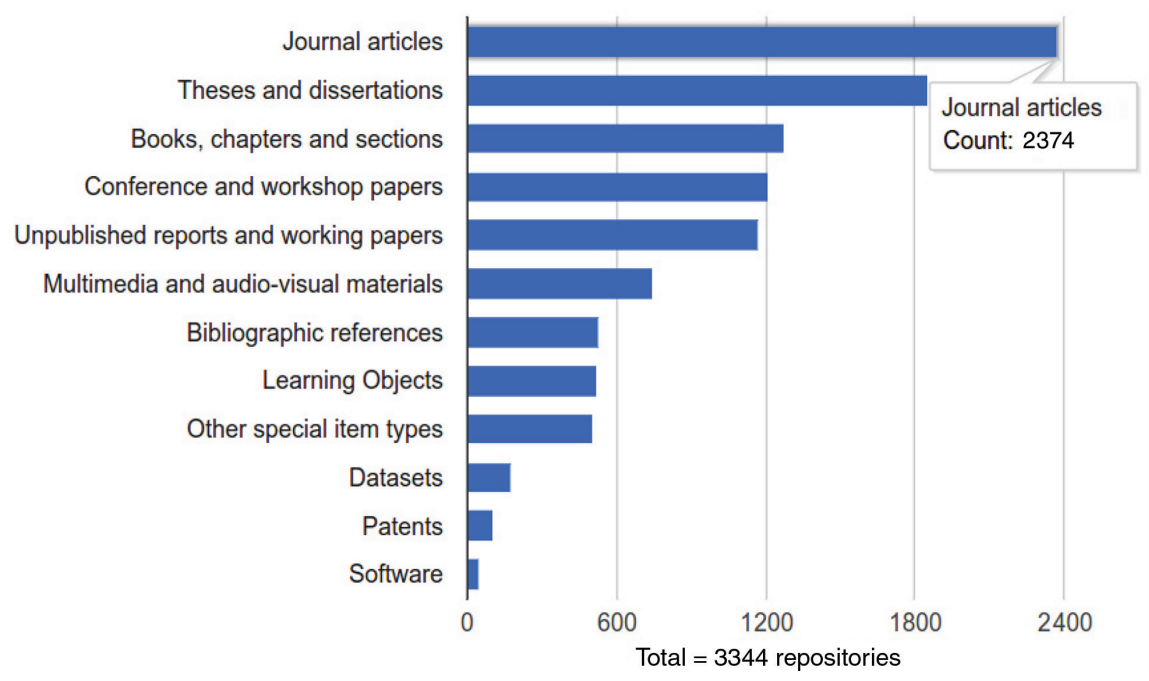

\subsubsection{Ingest/Submission Policy}

This Ingest policy has two parts viz. types (e.g. bitstreams ingest and metadata ingest) and persons responsible for ingest items. Generally, authorized members such as faculty members or academicians, IR staff members, researchers (even outsiders who are closely associated with the organization) are eligible to deposit items along with the metadata to the repository. Here, $22(43 \%)$ repositories have this policy and only two OARs (sl.no. $45,50)$ have stated that authors can submit their own works for archiving. A total of six (6) OARs (s.l.no. 1, 2, 45, 46, 49, 50) have stated that accredited members of the organization or their delegated agents, on behalf of the authors, are also eligible to submit items to the system. Only three (3) systems (sl.no. 45, 46, 50) respect an embargo imposed by publishers or funders and have clearly stated that items can be deposited at any time into the repository, but it will not be made publicly visible until publishers' or funders' embargo period has expired. Only one (1) system has recommended submission in a recommended file format (sl.no. 48). In practice, contributors provide metadata at the time of submission but the final format should be decided by librarians. 


\subsection{Advocacy and Promotion Policy}

Advocacy within the organization has become a crucial aspect of the 'Institutional Repositories' movement (Chan, Kwok, \& Yip, 2005) as 'IR' is relatively new and the academic community is unfamiliar about the concept (Davis \& Connelly, 2007; Foster \& Gibbons, 2005; Ghosh, 2011; Ratanya, 2017; Rieh et al., 2007; Swan \& Brown, 2005; Troll Covey, 2011; Watson, 2007). As a result, the majority of repositories lack content and are uneven in contributing objects to the 'IR' (Figure 3).

After analyzing COAR-member repositories, it is found that the average number of objects deposited to the IR is very low and the growth rate of deposition is not satisfactory. Generally, old repositories (in terms of origin) managed and maintained by elite organizations have large number of varieties of objects and maintain consistency over time in term of addition of record numbers in comparison to those OARs that are at implementation stages or in their infancy. And, repositories started functioning long ago upload objects on a regular basis. Only 2 repositories have more than 200,000 items and fall under category- 1 whereas another 3 systems fall under category-2 having content range 100,001-200,000. A total of 10 repositories have uploaded less than 5000 items whereas another 7 systems fall under category-2 having more than 5000 items (Figure 3). Only two (2) repositories did not mention their total number of objects.

Fig. 3: Collection strength of OARs.

$\begin{array}{ccc}\text { Category } & \text { Range of items } & \text { No. of OARs } \\ \text { C-7 } & \text { Up to } 5000 & 10 \\ \text { C-2 } & 5001-10,000 & 7 \\ \text { C-3 } & 10,001-20,000 & 8 \\ \text { C-4 } & 20,001-50,000 & 10 \\ \text { C-3 } & 50,001-100,000 & 9 \\ \text { C-2 } & 100,001-200,000 & 3 \\ \text { C-1 } & \text { Above 200,000 } & 2\end{array}$

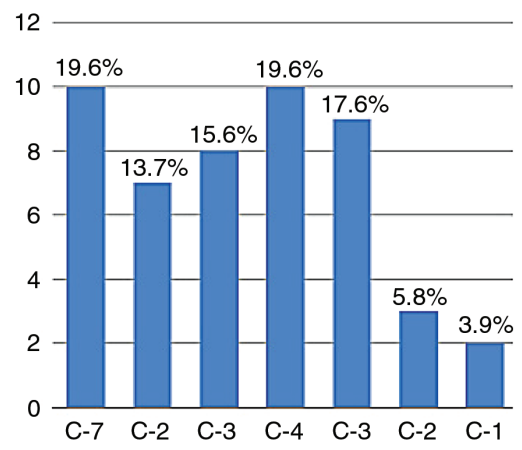


So, promoting the repository with faculty has become a challenging task for the repository administrators. To increase the continuous flow of contents to the IR, faculty participation is essential because they are both contributors as well as users of IR (Bamigbola, 2014; Kyriaki-Manessi, Koulouris, Giannakopoulos, \& Zervos, 2013). Carr and Brody (2007) stated that the key to a successful repository is sustained deposits and to achieve sustained deposits, community engagement is recommended (Henty, 2007). In addition, several other advocacy activities such as continuous marketing and promotion (Leary, Lundstrom, \& Martin, 2012; Troll Covey, 2011); collaboration and participation (Aschenbrenner, Blanke, Flanders, Hedge, \& O'Steen, 2008; Lynch, 2003; Thibodeau, 2007); providing incentives (Cullen \& Chawner, 2008; Giesecke, 2011; Xia et al., 2012) for the depositors may be adopted in acquiring content into IR.

In practice, there are no such elements in any of the IRs under study. The study of the collection development and growth rate (in terms of total number of objects uploaded) shows that growth is not expected. So advocacy must be the part of any IR system. Johnson (2008) has rightly said that 'advocacy is a route to achieve the crucial goal, real cultural change'.

\subsection{Copyright and Licensing Policy}

Generally, IRs hold items that may be owned by the institution, the author or the publisher (Gadd, Oppenheim, \& Probets, 2003). So, it is desirable to have rights management mechanisms in place to allow or restrict access to content (Crow, 2002). This policy specifies what users can do with the content. Generally, content contributors grant a non-exclusive right to reproduce, translate and/or distribute the work (including the abstract) worldwide in print and electronic format and in any medium. But studies (Gadd, Oppenheim \& Probets, 2004; Xia et al., 2012) recommended the use of Creative Commons licenses to express the rights attached to individual research papers.

After reviewing all COAR member repositories, it is found that $35(68.6 \%)$ repositories have mentioned this policy and twenty three (23) repositories suggest authors to retain the key rights. Only seven (7) repositories have clearly stated their licensing model e.g. CC (Creative Commons)-BY or equivalent 
and another seven (7) repositories require an open license but did not mention its type. This CC license is used when an author likes to give access to the content in the public domain and users can modify, re-use, or re-distribute the licensed work even for commercial purposes subject to proper acknowledgement. Only three (3) repositories reported that authors willingly grant key rights to the institution whereas another two (2) institutions or funders retain key rights instead of granting it to the authors (mostly mandatory).

\subsection{Data Access Policy}

By default, items in the repositories should not have any access restrictions and should be "...accessible to end users both within and outside of the institution, with few if any barriers to access" (Crow, 2002). However, a variety of legitimate circumstances might require an institution to limit access to a particular content to a specific set of users.

It is found that $37(72 \%)$ repositories have mentioned this data access policy. Some of the repositories (sl.no. 16, 17, 24, 37, 47) do not hold all full-text items whereas some other repositories (sl.no. 23, 30, 37, 48, 49, 51) support restriction on access under special circumstances and full-text access (in whole or in part) is limited only to the registered members. For example, in the case of Lund University (sl.no. 37), only a few items are available as full text, and many are only bibliographic entries or links to external service providers (e.g. e-journal sites) which may or may not be available to external users, depending upon local or personal subscriptions. In case of the Humboldt University (sl. no. 15), some items are not available via OA and are only available as metadata (bibliographic record) entries.

MIT (s.l.no. 49) has explicitly mentioned that the community retains the right to limit access to content at the item level either to MIT only or to specific individuals or groups. It is the responsibility of the communities to establish access control policies for content in their collections, or community level. Like MIT, the University of California (sl.no. 51) reported that full text access may be restricted to members of the community whereas Cornell follows three types of access (i.e. anyone; Caltech users only; repository administrators only) and imposes restriction on access to full-text for specific cases for specific items for a certain period. Although copies may be requested in this 
period (sl.no. 30). The University of Melbourne (sl. no. 2) allows restriction on access and in some of the cases no attached file are available.

Now the question arises how far COAR member repositories are open? How many documents are available in full-text? Though there are clear differences in opinions among the open access advocates regarding the concept of 'openness', Chan (2014) stated that the concept 'openness' is not simply about gaining access to knowledge, but about the right to participate in the knowledge production process, driven by issues that are of local relevance, rather than research agendas set elsewhere or from the top down.

It is clear from Annex 1 that only ten (10) repositories have mentioned that an object has to be made OA only 'when publisher permits'. Another nine (9) repositories have suggested providing access to the contents 'by end of policy-permitted embargo'. On the other hand, another four (4) repositories (sl.no. 15, 27, 43, 50) support providing access 'as soon as the deposit is completed'. It is also found that 49 (96\%) repositories (37 OARs from column 6 and 12 OARs from column 7 of Annex-1) support some form of access restriction. It is also clear from the section 5.1 viz. Archiving policies that repositories do not provide immediate access to the contents and most of the cases objects are made available only after the embargo period is over or when publishers allow. Interestingly, when the embargo period expires, the picture varies and the percentage of availability of OA full-text articles increases.

Here, only some significant results have been mentioned. For example, Queensland University of Technology (sl. no. 1) has only 56.0\% full-text documents whereas $48.0 \%$ objects are available in open-access mode. Ghent University (sl. no. 3) has 110,892 (45.5\%), out of a total of 243,441 objects, full-text documents whereas $39,338(16.1 \%)$ are available in open-access. University of Konstanz (sl. no. 138) has 18,276 full-text documents whereas 17,217 have no full-text. University of Regensburg (sl. no. 16) contains 61\% full text documents and only $60 \%$ are open access. Uppsala University Library (sl. no. 40) holds 764,047 items and only 121,402 (15.8\%) items are full-text.

It is also found that openness rates vary from objects to objects or disciplines to disciplines. And, important documents like journal articles, PhD theses, books or book chapters are less open and restricted than others due to copyright or embargo policy. For example, the University of Edinburgh imposes 
restriction on access in case of PhD theses (submitted recently). In case of Cornell University, some of the theses are restricted up to 2-5 years.

After analyzing the COAR repositories, it may be concluded that some of the OARs do not house all full text items and some items are not available via OA. Even, some are only available to registered members. Generally, OARs impose restriction on access (column 7 of Annex 1) and follow the publisher's policy (column 5 of Annex 1) before making content open access.

\subsection{Embargo Policy}

Determining the embargo period or retention period is another aspect to be considered before depositing objects into open access repositories (OARs) or making them freely available to the public. Most of the publishers and funders impose a range of constraints in the form of embargoes in order to make profit during this embargo period. Basically, this policy works against the concept 'OA' as it does not provide immediate free full text access to the content. Generally, questions arise on what version (e.g. pre-print, post-print or published version) is to be deposited in the repository.

It is found that a majority of the repositories do not have this policy and majority of the repositories usually maintain 12 months duration as the most common embargo period. But there are a few organizations that allow longer embargoes depending upon the nature of the subject and the type of document (ROARMAP, 2018). It is to be noted that COAR, in principle, supports embargoes of not more than 6 months for the life and physical sciences, and 12 months for social sciences and humanities.

Here, only 12 (23.5\%) repositories have their embargo policy and maintain a retention period, although this varies from subject to subject or discipline to discipline (Annex 1). Only thirteen (13) repositories have clearly stated twelve (12) months as the embargo period where seven (7) repositories from the 'Science, Technology and Medicine' discipline and six (6) repositories from the 'Humanities and Social Sciences' discipline. Another five (5) repositories recommend maintaining six (6) months as the retention period where three (3) systems are from 'Science, Technology and Medicine' and another two (2) repositories are from the 'Humanities and Social Sciences' discipline (Figure 4). Only one (1) system (sl.no. 1) suggests following 12 months as the embargo period 
Fig. 4: Embargo policy.

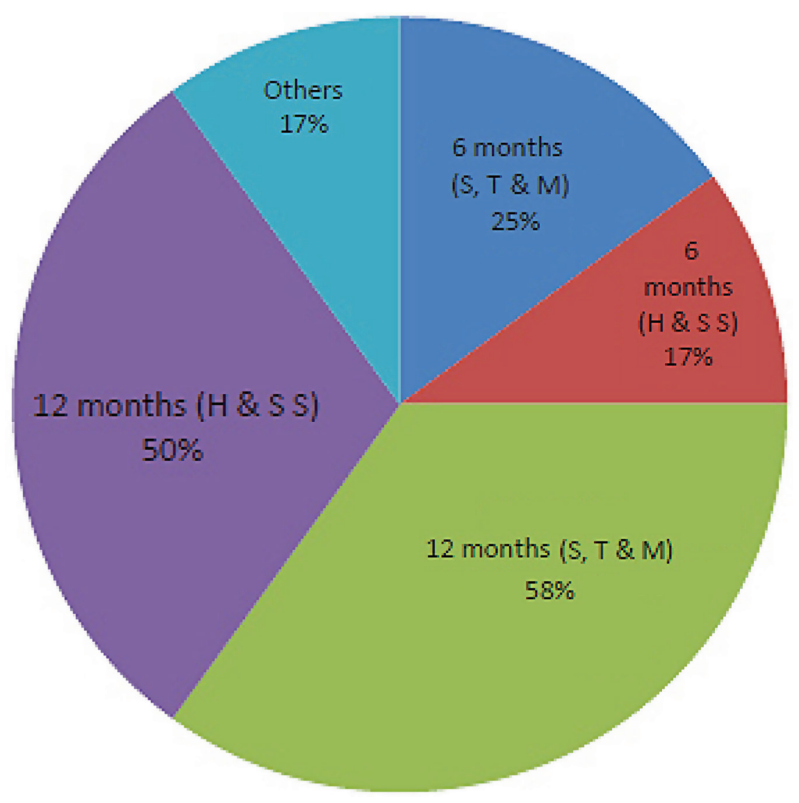

for all subjects whereas another (1) system (sl.no. 11) suggests maintaining 24 months as the retention period for a discipline like 'Science, Technology and Medicine'.

\subsection{Standards Support Policy}

This section discusses interoperability and metadata issues that ensure interoperability of diverse systems and facilitate the efficient dissemination of content.

\subsubsection{Interoperability}

IRs are by their nature usually designed to be OA and interoperable and a primary goal is to be able to link up with other similar archives (Crow, 2002). Several studies (Alipour-Hafezi, Horri, Shiri, \& Ghaebi, 2010; Eaton, 2008; Genoni, 2004; Ginsparg, Luce, \& Van de Sompel, 1999; Horwood, Sullivan, 
Young, \& Garner, 2004; Hunter \& Guy, 2004; Johnson, 2002; Khazraee, Moaddeli, Sanjari, \& Shakeri, 2011; Lynch, 2003; Mazurek, Stroinski, Werla, \& Węglarz, 2006; Miller, 2004; Peset, Ferrer, Subirats, \& Muñoz, 2007; Van de Sompel \& Lagoze, 2000; Westell, 2006) have advocated establishing OAI compliant repositories in order to provide access to the content. There are so many initiatives at the international level to improve interoperability between repositories, such as DL.org (http://www.dlorg.eu/), OpenAIRE (http://openaire.eu/), Driver project (http://driver-repository.eu/), JISC (http://ie-repository.jisc.ac.Uk/430/1/OCRIS Report.pdf).

It is found that all the repositories use the OAI-PMH protocol for allowing their metadata to be harvested by other systems. The validity and authenticity of base OAI-PMH URLs of repositories have been checked by the 'Oval' validator tool, a service provided by Bielefeld Academic Search Engine (BASE) (http://oval.base-search.net/). Some of the repositories are OAI-ORE compliant and support harvesting content (bitstreams and metadata) from an external OAI-PMH/OAI-ORE server.

\subsubsection{Metadata}

Standardized or good quality metadata is important for describing and managing digital objects of different formats (Moulaison Sandy, \& Dykas, 2016; Ochoa \& Duval, 2009; Park, 2009; Robertson, 2005) and it enables end users to easily and effectively search, find and retrieve information from the repository (Jones, 2007; Jones et al., 2006; Pinfield, Gardner, \& MacColl, 2002). But repositories differ widely in the handling of metadata schema (Gibbons, 2004) and the qualified Dublin Core has been the choice of researchers for organizing and harvesting open knowledge objects (Gibbons, 2004; Teli, 2015; van der Graaf \& van Eijndhoven, 2008). Additional or extended metadata schemas may be adopted for domain specific datasets (DINI, 2007; Green et al., 2009).

It is found that a total of $16(31 \%)$ repositories have a stated metadata policy and, in principle, support metadata to be re-used for 'not-for-profit purposes'. Though, in a few cases, it is missing in their policy documentation. Only content contributors or eligible depositors (generally authors) will provide metadata (sl. no. 49); if required, library staff may edit or create additional metadata (sl. no. 48). Only one system (sl. no. 2) stated that they use a 
qualified version of the Dublin Core (DC) schema as a descriptive metadata standard.

\subsection{Preservation Policy}

This policy ensures continued access to digital materials for as long as necessary (Hockx-Yu, 2006), as one of the features of IR is that it must be cumulative and perpetual (Crow, 2002). Generally, repositories accept many open file formats, and PDF is the common choice of almost all repository managers due to its suitability for long term preservation (Cervone, 2004; Pinfield, 2002; Rimkus, Padilla, Popp, \& Martin, 2014). Here, repositories have no formal preservation policy except for the recommendation of file formats that are likely to facilitate long-term preservation. Only $12(23.5 \%)$ repositories have this policy. Only three (3) systems (sl.no. 46, 49, 51) support techniques like migration to a new file format. In addition, MIT prefers emulation (for software), where necessary. Another three (3) systems (sl. no. 45, 46, 50) keep backing up their files according to current best practices and transfer the database to another appropriate archive on the system.

\subsection{Withdrawal Policy}

Studies strongly discourage withdrawal of items (Probets \& Jenkins, 2006; Ware, 2004a) because one definition of IRs is that items should be cumulative and perpetual (Johnson, 2002). Only six (6) repositories (sl. no. 2, 6, 46, 48, $49,50)$ have mentioned withdrawal of items under different circumstances. The common reasons are - plagiarism or copyright violation; request of the author; publishers' desire/publishers' rules; national security; falsified research etc. Though withdrawn items are not deleted per se, but are removed from public view.

\section{Key Findings}

It is quite obvious that weak or no policy framework at the local repository level is not the only factor for the slow rate of progress in populating open access repositories. There are many other major constraints to populating institutional repositories, which are sometimes external to the repository, 
including lack of awareness by researchers, lack of external policies by funders, and lack of technical staff, lack of support from the local authority, and in developing countries lack of infrastructural availability is also an important factor that is reducing expected growth of open access repositories. However, the main focus of this paper is solely on the local policy framework at the repository level as it is one such factor that may have far-reaching impact on the overall development of open access repositories. An open access repository that is developed from the beginning with a comprehensive policy framework may have better chances to survive and thrive in the long run.

A set of of observations have been identified by studying 51 COAR-affiliated OARs in view of the discussions in the foregoing subsections under section 4 . These observations may be related to different policy elements as discussed in section 4. The major observations are-house mainly textual data (section 4.2.1); no specific rules for managing submission workflow in order to check the content quality (section 4.2.2); deposit rate is low (section 4.3); no use of control vocabulary or any appropriate subject taxonomy for organizing and displaying collections (section 4.3); not a single repository has mentioned the type of Creative Commons license under which an item is to be published (section 4.4); not all items are available as full-text (section 4.5); contains metadata rather than full-text or no link to the fulltext (section 4.5); no uniformity in data access rules (section 4.5); access and usage statistics is not available (section 4.5); no use of domain-specific metadata schema for describing non-textual objects such as learning objects, dissertations and theses etc (section 4.7.2).

Apart from the above, policies like collection management, content quality, version, system management, user interface (see Annex 1) are not properly discussed in the literature.

\section{Recommendations}

In fact there is no 'one-size-fits-all' solution to implementing a policy framework in developing open access repositories as it varies hugely from region to region due to various factors as reported in the previous section. There are even differences amongst organizations and different countries have different approaches in terms of local conditions, infrastructural availability and 
national laws. This study shows the strength and weakness of COAR member repositories in respect of OA policies against different issues mentioned in Annex 1 and provides a general set of recommendations related to elements of a comprehensive OA policy framework. The major recommendations are:

- Repositories should recommend an archiving format for different types of objects (may follow PRONOM registry to achieve global compatibility) and should follow a mandatory deposit policy in order to capture $100 \%$ content produced by researchers or academicians;

- Most of the researchers are not aware about the advantages of Open Access content and they consider the archiving process as a complex, time consuming and additional burden. So, continuous advocacy/ promotional strategy on campus is required to be followed in raising awareness among researchers as well as rewarding researchers, so that incentives (Cullen \& Chawner, 2008; Schöpfel \& Prost, 2015; Xia et al., 2012) may be helpful in acquiring content from the faculties;

- Most of the repositories have minimum objects due to irregular deposition. Repository managers should encourage community members to upload more and more full-text items and, if not, should provide at least links (e.g url, doi etc.) to the full-text. The study also suggests following mediated deposit services/deposit (Armbruster, 2011; Pinfield, 2001) and appeals to library authorities to assist authors or submitters in the deposition process.

- Metadata of withdrawn items are required to be visible and searchable so that users can have an idea about the items;

- This study recommends the adoption of a qualified version Dublin Core (DC) as the metadata standard for organizing resources and also proposes to use domain specific metadata schemes for non-textual knowledge objects like theses, learning objects, datasets etc.

- Generally, authors unknowingly transfer copyrights to the publishers for articles to be published. This study suggests authors should follow the Creative Commons Attribution (CC-BY) licence in order to retain key rights so that they can re-use, re-mix or distribute it as per the Creative Commons (CC) license. In this context it may be noted that the 'author addendum' that allows modification of the publisher's agreement with the authors also allows authors to keep key rights to his/her works and this may help to achieve the greater objectives of OA movement; 
- Organization of items in collections under an IR, as far as subject descriptors are concerned, should be populated according to any standard control vocabulary tools like domain-specific thesaurus, DDC (Dewey Classification Scheme) etc;

- This study tolerates 'embargo' of any form imposed by publishers or any other organizations. But it is suggested to follow the 'ImmediateDeposit/Optional-Access' (IDOA) policy in order to ensure 100\% deposition of contents into the repositories;

- Establishment of global repository networks based on common standards of interoperability, as proposed by UNESCO (Mukhopadhyay, 2015), are essential to provide global access to the local research outputs.

\section{Conclusion}

After the successful journey over 25 years since 1991 (the first subject repository arXiv started functioning), OARs are in a critical situation when policy matters are concerned. Almost all the countries are now maintaining OARs and over $30 \%$ of OARs all over the world as stated earlier have been functioning without OA policies. In our study, the picture has gone from bad to worse and is quite alarming to the repository administrators. More than $70 \%$ of repositories support $2-4$ policies and only 16 OARs support more than 5 policies (column 16 of Annex 1). The majority of the repositories under study are below the average level as reported by Peter Millington (Millington, 2006), and are not up to the standard. But it is a good sign that $44(86 \%)$ OARs are registered with the ROARMAP database and only seven OARs (sl. no. 20, 21, $22,27,33,39,40)$ are not listed. Nevertheless, several issues within the policies are not stated in policy documents. Even OARs in developed countries are also facing the same problems in OA policy framework formulation. Policies like user interface/experience, multilinguality, versioning, quality control mechanisms, subject access system, are not covered in the documentation and are required to be properly formulated in the line of global recommendations. Even some of the issues (such as the archiving format, mandatory/ optional, collection as well as system management) within the policies are still missing. In this context, aligning repository networks and mandates is likely to be crucial in determining future repository development (Shearer, 2014). As stated earlier, there are differences among countries but the issues 
(Table 2) are almost the same. This study proposes some of the common areas (see Table 2) where policy proposals are required for smooth functioning of OARs. So, devising a common set of policies against pre-defined issues (as stated in Annex 1) based on existing best practices has been a challenging task for the repository developers. In view of these hard facts related to OA, this paper recommends, after analyzing the policy documentations of COAR member countries, a set of OA policy elements (included in section 6) that may be adopted by any OAR irrespective of size or type.

\section{References}

Alipour-Hafezi, M., Horri, A., Shiri, A., \& Ghaebi, A. (2010). Interoperability models in digital libraries: an overview. The Electronic Library, 28(3), 438-452. https://doi. org/10.1108/02640471011052016.

Armbruster, C. (2011). Open access policy implementation: first results compared. Learned Publishing, 24(4), 311-324. https:/ / onlinelibrary.wiley.com/doi/ epdf/10.1087/20110409.

Asamoah-Hassan, H. (2010). Alternative scholarly communication: management issues in a Ghanaian university. Library Management, 31(6), 420-426. https://doi. org/10.1108/01435121011066171.

Aschenbrenner, A., Blanke, T., Flanders, D., Hedge, M., \& O'Steen, B. (2008). The future of repositories? Patterns for (cross-)repository architectures. D-Lib Magazine, 14(11/12), n.p. Retrieved July 22, 2016, from http:/ / www.dlib.org/dlib/ november08/aschenbrenner/11aschenbrenner.html.

Bamigbola, A.A. (2014). Surveying attitude and use of institutional repositories (IRs) by faculty in agriculture disciplines: A case study. Procedia Social and Behavioral Sciences, 147, 505-509. https://doi.org/10.1016/j.sbspro.2014.07.145.

Barton, M.R., \& Waters, M.M. (2004). Creating an institutional repository. LEADIRS workbook. Cambridge, MA: MIT.

Carr, L., \& Brody, T. (2007). Size isn't everything: Sustainable repositories as evidenced by sustainable deposit profiles. D-Lib Magazine, 13(7/8), n.p. Retrieved October 10, 2016, from http://www.dlib.org/dlib/july07/carr/07carr.html.

Cervone, H.F. (2004). The repository adventure. Library Journal, 129(10), 44-46.

Chan, L. (2014). What role for open and collaborative science in development? University World News, 333, n.p. Retrieved July 9, 2017, from http://www. universityworldnews.com/article.php?story=20140905132026576. 
Bijan Kumar Roy et al.

Chan, D.L.H., Kwok, C.S.Y., \& Yip, S.K.F. (2005). Changing roles of reference librarians: the case of the HKUST institutional repository. Reference Services Review, 33(3), 268-282. https://doi.org/10.1108/00907320510611302.

Chantavaridou, E. (2009). Open access and institutional repositories in Greece: progress so far. OCLC Systems \& Services: International Digital Library Perspectives, 25(1), 47-59. https://doi.org/10.1108/10650750910931922.

Crow, R. (2002). The case for institutional repositories: A SPARC position paper. Washington, DC: The Scholarly Publishing \& Academic Resources Coalition. Retrieved August 8, 2018, from http://www.sparc.arl.org/sites/default/files/ media files/instrepo.pdf.

Cullen, R., \& Chawner, B. (2008). Institutional repositories in New Zealand: comparing institutional strategies for digital preservation and discovery. Digital Discovery: Strategies and Solutions: Proceedings of the $29^{\text {th }}$ Annual IATUL Conferences (April 21-24, 2008, AUT University, Auckland, New Zealand). Paper 18. Retrieved June 22, 2015, from http://docs.lib.purdue.edu/iatul/2008/papers/18.

Davis, P., \& Connelly, M.J.L. (2007). Institutional repositories. Evaluating the reasons for non-use of Cornell University's installation of DSpace. D-Lib Magazine, 13(3/4), n.p. Retrieved July 17, 2016, from http://www.dlib.org/dlib/march07/ davis/03davis.html.

Dhanavandan, S., \& Tamizhchelvan, M. (2014). Institutional repositories in South Asian countries: a study on trends and development. Brazilian Journal of Information Science: Research Trends, 8(1/2), n.p. Retrieved March 21, 2017, from http://www2.marilia.unesp.br/revistas/index.php/bjis/article/ download/4251/3090.

Dhanavandan, S., \& Mary, M.I. (2015). The growth and development of institutional repositories in Brazil. Brazilian Journal of Information Science: Research Trends, 9(1), n.p. Retrieved June 10, 2017, from https://doi.org/10.5016/brajis.v9i1.5221.

Dhanavandan, S., \& Tamizhchelvan, M.C. (2015). Institutional repositories in BRICS countries: a study. International Journal of Knowledge Content Development E Technology, 5(1), 33-47. https://doi.org/10.5865/IJKCT.2015.5.1.033.

DINI. (2007). DINI-certificate for document and publication services 2007. Retrieved May 10, 2016, from http://nbn-resolving.de/urn:nbn:de:kobv:11-10075687.

Eaton, J. (2008). Using the open archives initiative protocol for metadata harvesting. Program: Electronic Library and Information Systems, 42(4), 450-452. https://doi. org/10.1108/00330330810912133.

Foster, N.F., \& Gibbons, S. (2005). Understanding faculty to improve content recruitment for institutional repositories. D-Lib Magazine 11(1), n.p. Retrieved May 10, 2016, from http://www.dlib.org/dlib/january05/foster/01foster.html. 
Gadd, E., Oppenheim, C., \& Probets, S. (2003). RoMEO studies 1: the impact of copyright ownership on author-self-archiving. Journal of Documentation, 59(3), 243-277. https://doi.org/10.1108/00220410310698239.

Gadd, E., Oppenheim, C., \& Probets, S. (2004). RoMEO studies 6: rights metadata for open archiving. Program: Electronic Library and Information Systems, 38(1), 5-14. https://doi.org/10.1108/00330330410699036.

Gargiulo, P., \& Cassella, M. (2010). Open access in Italy: an overview. In L. Anglada \& E. Abadal (Eds.), Open access in Southern European countries (pp. 63-82). Madrid: FECYT. Retrieved September 02, 2016, from https://www.researchgate.net/ publication/43404460 Open Access in Italy.

Genoni, P. (2004). Content in institutional repositories: a collection management issue. Library Management, 25(6/7), 300-306. https://doi. org $/ 10.1108 / 01435120410547968$.

George, L.A. (2006). SPEC online surveys: SPEC survey on institutional repositories. Retrieved March 22, 2017, from http://createchange.org/spec/surveys/index.html.

Ghosh, M. (2011). Advocacy for open access: a selected review of the literature and resource list. Library Hi Tech News, 28(2), 19-23. https:/ / doi. org/10.1108/07419051111135245.

Gibbons, S. (2004). Establishing an institutional repository. Library Technology Reports, 40(4), 1-68. http://dx.doi.org/10.5860/ltr.40n4.

Giesecke, J. (2011). Institutional repositories: keys to success. Journal of Library Administration, 51(5/6), 529-542. https://doi.org/10.1080/01930826.2011.589340.

Ginsparg, P., Luce, R., \& Van de Sompel, H. (1999). The Open Archives Initiative aimed at the further promotion of author self-archived solutions. Retrieved August 7, 2016, from http://www.openarchives.org/meetings/SantaFe1999/ups-invitation-ori.htm.

Green, A., Macdonald, S., \& Rice, R. (2009). Policy making for research data in repositories: a guide. Retrieved August 8, 2018, from https://www.coar-repositories. org/files/guide.pdf.

Henty, M. (2007). Ten major issues in providing a repository service in Australian universities. D-Lib Magazine, 13(5/6), n.p. Retrieved September 23, 2016, from http:// www.dlib.org/dlib/may07/henty/05henty.html.

Hockx-Yu, H. (2006). Digital preservation in the context of institutional repositories. Program: Electronic Library and Information Systems, 40(3), 232-243. https:/ / doi. org/10.1108/00330330610681312.

Horwood, L., Sullivan, S., Young, E., \& Garner, J. (2004). OAI compliant institutional repositories and the role of library staff. Library Management, 25(4/5), 170-176. 
Hunter, P., \& Guy, M. (2004). Metadata for harvesting: the open archives initiative, and how to find things on the web. The Electronic Library, 22(2), 168-174. https://doi. org $/ 10.1108 / 02640470410533434$.

Johnson, R.K. (2002). Institutional repositories. Partnering with faculty to enhance scholarly:/ /. D-Lib Magazine, 8(11), n.p.. Retrieved October 30, 2016, from http:// www.dlib.org/dlib/november02/johnson/11johnson.html.

Johnson, G.J. (2008). In the kingdom of the blind: successfully implementing institutional repositories in the United Kingdom and the Sherpa partnership experience. New Review of Academic Librarianship, 13(1-2), 13-33. https://doi. org $/ 10.1080 / 13614530701868652$.

Jones, C. (2007). Institutional repositories: content and culture in an open access environment. Oxford: Chandos Publishing.

Jones, R.E., Andrew, T., \& MacColl, J. (2006). The institutional repository. Oxford: Chandos Publishing.

Khazraee, E., Moaddeli, S., Sanjari, A., \& Shakeri, S. (2011). EIAH data model: Semantic interoperability among distributed digital repositories. Aslib Proceedings, 63(1), 46-56. https://doi.org/10.1108/00012531111103777.

Kyriaki-Manessi, D., Koulouris, A., Giannakopoulos, G., \& Zervos, S. (2013).

Exploratory research regarding faculty attitudes towards the institutional repository and self archiving. Procedia - Social and Behavioral Sciences, 73, 777-784. https://doi. org/10.1016/j.sbspro.2013.02.118.

Leary, H., Lundstrom, K., \& Martin, P. (2012). Copyright solutions for institutional repositories: a collaboration with subject librarians. Journal of Library Innovation, 3(1), 101-110. Retrieved August 8, 2018, from https://www.dropbox.com/ s/2jizyib4be4s46t/Copyright.pdf?dl=1.

Lynch, C.A. (2003). Institutional repositories: Essential infrastructure for scholarship in the digital age. ARL Bimonthly Report, 226. Retrieved August 8, 2018, from http://old.arl. org/resources/pubs/br/br226/br226ir print.shtml.

Markey, K., Rieh, S.Y., St. Jean, B., Kim, J., \& Yakel, E. (2007). Census of institutional repositories in the United States: MIRACLE project research findings. Washington, DC: Council on Library and Information Resources. Retrieved March 22, 2015, from https://www.clir.org/pubs/reports/pub140/.

Markland, M. (2006). Institutional repositories in the UK: what can the Google user find there? Journal of Librarianship \& Information Science, 38(4), 221-228. https:/ / doi. org/10.1177/0961000606070587.

Mazurek, C., Stroinski, M., Werla, M., \& Węglarz, J. (2006). Metadata harvesting in regional digital libraries in the PIONIER network. Campus-Wide Information Systems, 23(4), 241-253. https://doi.org/10.1108/10650740610704117. 
Melero, R., Abadal, E., Abad, F., \& Rodríguez-Gairín, J.M. (2009). The situation of open access institutional repositories in Spain: 2009 report. Information Research, 14(4), n.p. (paper 415). Retrieved November 01, 2015, from http://www.informationr.net/ ir/14-4/paper415.html.

Miller, P. (2004). Interoperability. What is it and why should I want it? Ariadne, n.p.. Retrieved March 2, 2016, from http://www.ariadne.ac.uk/issue24/interoperability/.

Millington, P. (2006). Moving forward with the OpenDOAR Directory. Paper presented at the $8^{\text {th }}$ International Conference on Current Research Information Systems (May 11-13, 2006, Bergen) [PowerPoint]. Retrieved July 12, 2016, from http://www. opendoar.org/documents/BergenPresentation20060512Handouts.ppt.

Moulaison Sandy, H., \& Dykas, F. (2016). High-quality metadata and repository staffing: Perceptions of United States-based OpenDOAR participants. Cataloging E Classification Quarterly, 54(2), 101-116. Doi: $\underline{\text { http://dx.doi.org/10.1080/01639374.2015.1116480. }}$

Mukhopadhyay, P. (2015). Open access for library schools: Module 4: Interoperability and retrieval. UNESCO, Paris. Retrieved February 27, 2018, from http://unesdoc.unesco. org/images/0023/002321/232199E.pdf.

Ochoa, X., \& Duval, E. (2009). Automatic evaluation of metadata quality in digital repositories. International Journal on Digital Libraries, 10(2/3), 67-91. https:/ / doi. org/10.1007/s00799-009-0054-4.

OpenDOAR (2018). The directory of open access repositories - OpenDOAR [Home page]. Retrieved February 15, 2018, from http://www.opendoar.org/.

Park, J. (2009). Metadata quality in digital repositories: a survey of the current state of the art. Cataloging E Classification Quarterly, 47(3/4), 213-228. https://doi. org $/ 10.1080 / 01639370902737240$.

Peset, F., Ferrer, A., Subirats, I., \& Muñoz, A. (2007). Use of OAI protocol and its impact in digital libraries: a case study in Spain, Portugal and Latin America. In A.R.D Prasad \& D.P. Madalli (Eds.), International Conference on Semantic Web and Digital Libraries (February 21-23, 2007, Bangalore) (pp. 459-471). Bangalore: DRTC. Retrieved August 8, 2018, from http:/ / eprints.rclis.org/10087/.

Pinfield, S. (2001). How do physicists use an e-print archive? Implications for institutional e-print services. D-Lib Magazine, 7(12), n.p. Retrieved January 15, 2016, from http://www.dlib.org/dlib/december01/pinfield/12pinfield.html.

Pinfield, S. (2002). Creating institutional e-print repositories. Serials, 15(3), 261-264. https://doi.org/10.1629/15261.

Pinfield, S. (2003). Open archives and UK institutions. D-Lib Magazine, 9(3), n.p. https://doi.org/10.1045/march2003-pinfield. 
Pinfield, S., Gardner, M., \& MacColl, J. (2002). Setting up an institutional e-print archive. Ariadne, 31, n.p. Retrieved from May 12, 2016, from http://www.ariadne. ac.uk/issue31/eprint-archives/.

Probets, S., \& Jenkins, C. (2006). Documentation for institutional repositories. Learned Publishing, 19(1), 57-71. https://doi.org/10.1087/095315106775122556.

Ratanya, F.C. (2017). Institutional repository: access and use by academic staff at Egerton University, Kenya. Library Management, 38(4/5), 276-284. https://doi. org/10.1108/LM-02-2017-0018.

Rieh, S.Y., Markey, K., St. Jean, B., Yakel, E., \& Kim, J. (2007). Census of institutional repositories in the US. D-Lib magazine, 13(11/12), n.p. Retrieved May 26, 2017, from http://www.dlib.org/dlib/november07/rieh/11rieh.html.

Rieh, S.Y., St. Jean, B., Yakel, E., Markey, K., \& Kim, J. (2008). Perception and experiences of staff in the planning and implementation of institutional repositories. Library Trends, 57(2), 168-190. https://doi.org/10.1353/lib.0.0027.

Rimkus, K., Padilla, T., Popp, T., \& Martin, G. (2014). Digital preservation file format policies of ARL member libraries: an analysis. D-Lib Magazine, 20(3/4), n.p. Retrieved May 22, 2016, from www.dlib.org/dlib/march14/rimkus/03rimkus.html.

ROAR. (2018). Registry of open access repositories [Home page]. Retrieved February 12, 2018, from http://roar.eprints.org/.

ROARMAP. (2018). Registry of open access repositories mandates and policies [Home page]. Retrieved February 10, 2018, from http://roarmap.eprints.org.

Robertson, R.J. (2005). Metadata quality: implications for library and information science professionals. Library Review, 54(5), 295-300. https://doi. org $/ 10.1108 / 00242530510600543$.

Roy, B.K., Biswas, S.C., \& Mukhopadhyay, P. (2012a). An analytical study of onstitutional digital repositories in India. Library Philosophy and Practice, 2012, n.p. (paper 692). Retrieved November 3, 2016, from http://digitalcommons.unl.edu/ libphilprac/692.

Roy, B.K., Biswas, S.C., \& Mukhopadhyay, P. (2012b). Open access repositories in Asia: From SAARC to Asian Tigers. Library Philosophy and Practice, 2012, n.p. (paper 808). Retrieved December 12, 2016, from http:/ / digitalcommons.unl.edu/ libphilprac/808.

Roy, B.K., Biswas, S.C., \& Mukhopadhyay, P. (2013). Global visibility of Indian Open Access Institutional Digital Repositories. International Research: Journal of Library $\mathcal{E}$ Information Science, 3(1), 182-194. Retrieved August 7, 2018, from http://irjlis.com/ wp-content/uploads/2013/07/13 IR096.pdf. 
Roy, B.K., Biswas, S.C., \& Mukhopadhyay, P. (2015).Trends and developments of open access repository movement in Europe. International Research: Journal of Library and Information Science, 5(3), 407-422. Retrieved August 7, 2018, from https://www.researchgate.net/profile/Bijan Roy4/publication/299489566 Trends and Developments of Open Access Repository Movement in Europe/ links/56fba24408ae1b40b805fc00/Trends-and-Developments-of-Open-AccessRepository-Movement-in-Europe.pdf.

Roy, B.K., Biswas, S.C., \& Mukhopadhyay, P. (2016). The COAPI cats: the current state of open access repository movement and policy documentations. International Journal of Knowledge Content Development \& Technology, 6(1), 69-84. https://doi.org/10.5865/ IIKCT.2016.6.1.069.

Schöpfel, J., \& Prost, H. (2015). Degrees of openness: grey literature in institutional repositories. Grey Journal, 11(2), 103-112. Retrieved August 8, 2018, from https://hal. univ-lille3.fr/hal-01290339/document.

Shearer, K. (2005). Institutional repositories: the evolution of scholarly communication. Retrieved April 30, 2015, from http://www.carl-abrc.ca/projects/institutional repositories/ppt/CACUL2-Apr05.ppt.

Shearer, K. (2014). Towards a seamless global research infrastructure: Report of the Aligning Repository Networks Meeting. Retrieved June 3, 2017, from https:/ / www.coarrepositories.org/files/Aligning-Repository-Networks-Meeting-Report.pdf.

Shreeves, S., \& Cragin, M.H. (2008). Introduction: institutional repositories: Current state and future. Library Trends, 57(2), 89-97. https://doi.org/10.1353/lib.0.0037.

Swan, A. (2012). Policy guidelines for the development and promotion of open access. France: UNESCO. Retrieved March 22, 2016, from http://unesdoc.unesco.org/ images/0021/002158/215863e.pdf.

Swan, A., \& Brown, S. (2005). Open access self archiving: an author study. Truro, UK: Key Perspectives Ltd. Retrieved January 20, 2016, from http://cogprints.org/4385/1/ jisc2.pdf.

Swan, A., Gargouri, Y., Hunt, M., \& Harnad, S. (2015). PASTEUR4OA Project. Open access policy: numbers, analysis, effectiveness. Retrieved July 15, 2016, from http:// eprints.soton.ac.uk/375854/1/PASTEUR4OA3.pdf.

Teli, S. (2015). Metadata harvesting from selected institutional digital repositories in India: a model to build a central repository. International Journal of Innovative Research in Science, Engineering and Technology, 4(4), 1935-1942. https://doi.org/10.15680/ ijirset.2015.0404018.

Thibodeau, K. (2007). If you build it, will it fly? Criteria for success in a digital repository. Journal of Digital Information, 8(2) 1-5. Retrieved March 12, 2016 from http://journals.tdl.org/jodi/index.php/jodi/article/viewArticle/197/174. 
Troll Covey, D. (2011). Recruiting content for the institutional repository: the barriers exceed the benefits. Journal of Digital Information, 12(3), 1-18. Retrieved Augusut 8, 2018, from https://journals.tdl.org/jodi/index.php/jodi/article/view/2068.

Van de Sompel, H., \& Lagoze, C. (2000). The Sante Fe convention of the open archives initiative. D-Lib Magazine, 6(2), n.p. Retrieved April 21, 2016, from www.dlib.org/ dlib/february00/vandesompel-oai/02vandesompel-oai.html.

van der Graaf, M., \& van Eijndhoven, K. (2008). The European repository landscape. Amsterdam: Amsterdam University Press.

van Westrienen, G., \& Lynch, C.A. (2005). Academic institutional repositories: Deployment status in 13 nations as of mid 2005. D-Lib Magazine, 11(9), n.p. https:// doi.org/10.1045/september2005westrienen.

Ware, M. (2004a). Publisher and library/learning solutions (PALS): pathfinder research on web-based repositories: Final report. Bristol: Mark Ware Consulting Ltd. Retrieved August 15, 2015, from https://mrkwr.files.wordpress.com/2006/11/pals-report-oninstitutional-repositories.pdf.

Ware, M. (2004b). Institutional repositories and scholarly publishing. Learned Publishing, 17(2), 115-124. https:/ / onlinelibrary.wiley.com/doi/epdf/10.1087/09531 $\underline{5104322958490 .}$.

Watson, S. (2007). Authors' attitudes to, and awareness and use of, a university institutional repository. Serials, 20(3), 225-230. https://doi.org/10.1629/20225.

Westell, M. (2006). Institutional repositories: proposed indicators of success. Library Hi Tech, 24(2), 211-226. https://doi.org/10.1108/07378830610669583.

Xia, J., Gilchrist, S.B., Smith, N.X.P., Kingery, J.A., Radecki, J.R., Wilhelm, M.L., ... Mahn, A.J. (2012). A review of open access self-archiving mandate policies. Portal: Libraries and the Academy, 12(1), 85-102. https://doi.org/10.1353/pla.2012.0000.

\section{Notes}

${ }^{1}$ http://www.opendoar.org/.

${ }^{2}$ http://roarmap.eprints.org.

${ }^{3}$ http://roar.eprints.org/. 


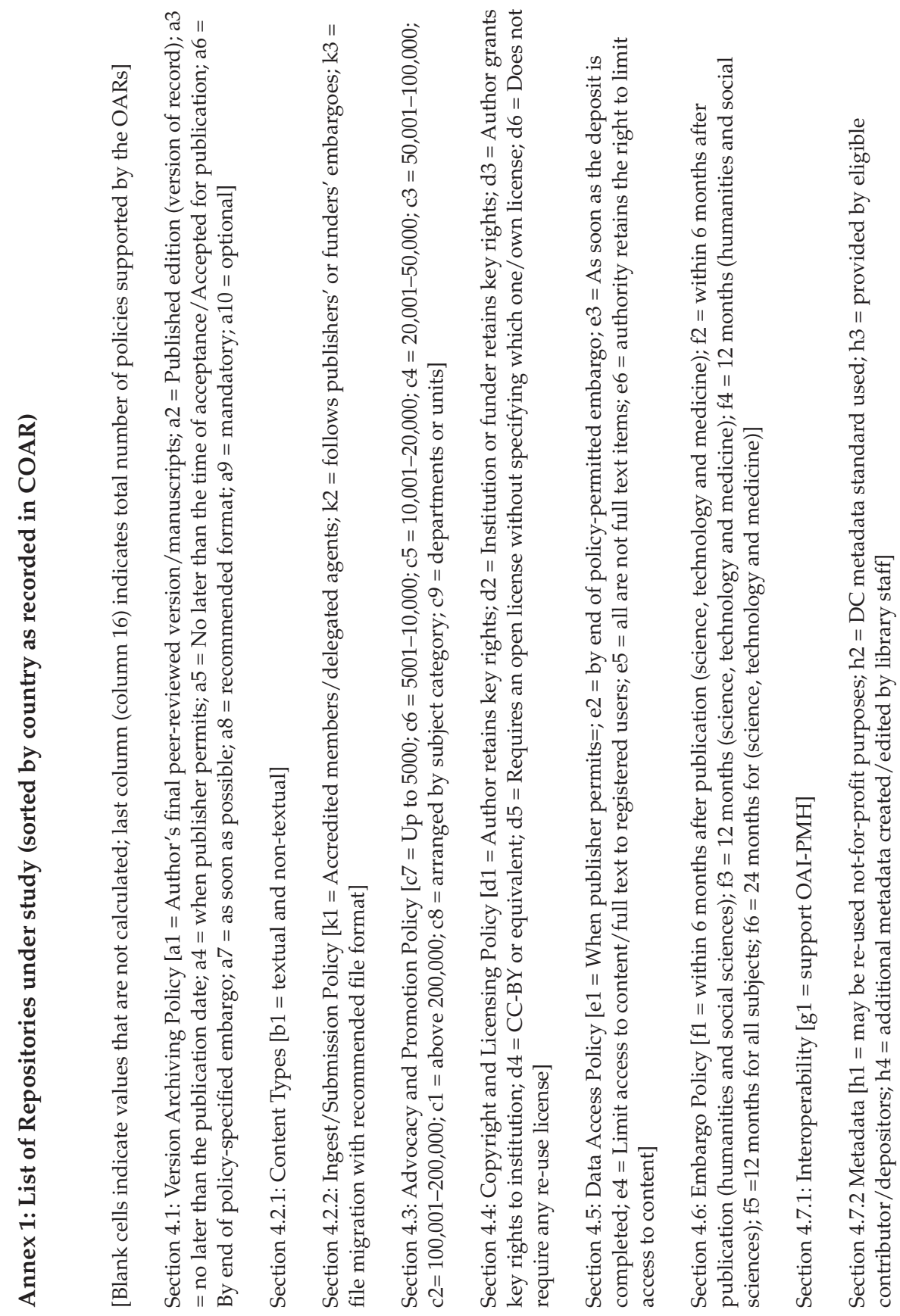


Bijan Kumar Roy et al.
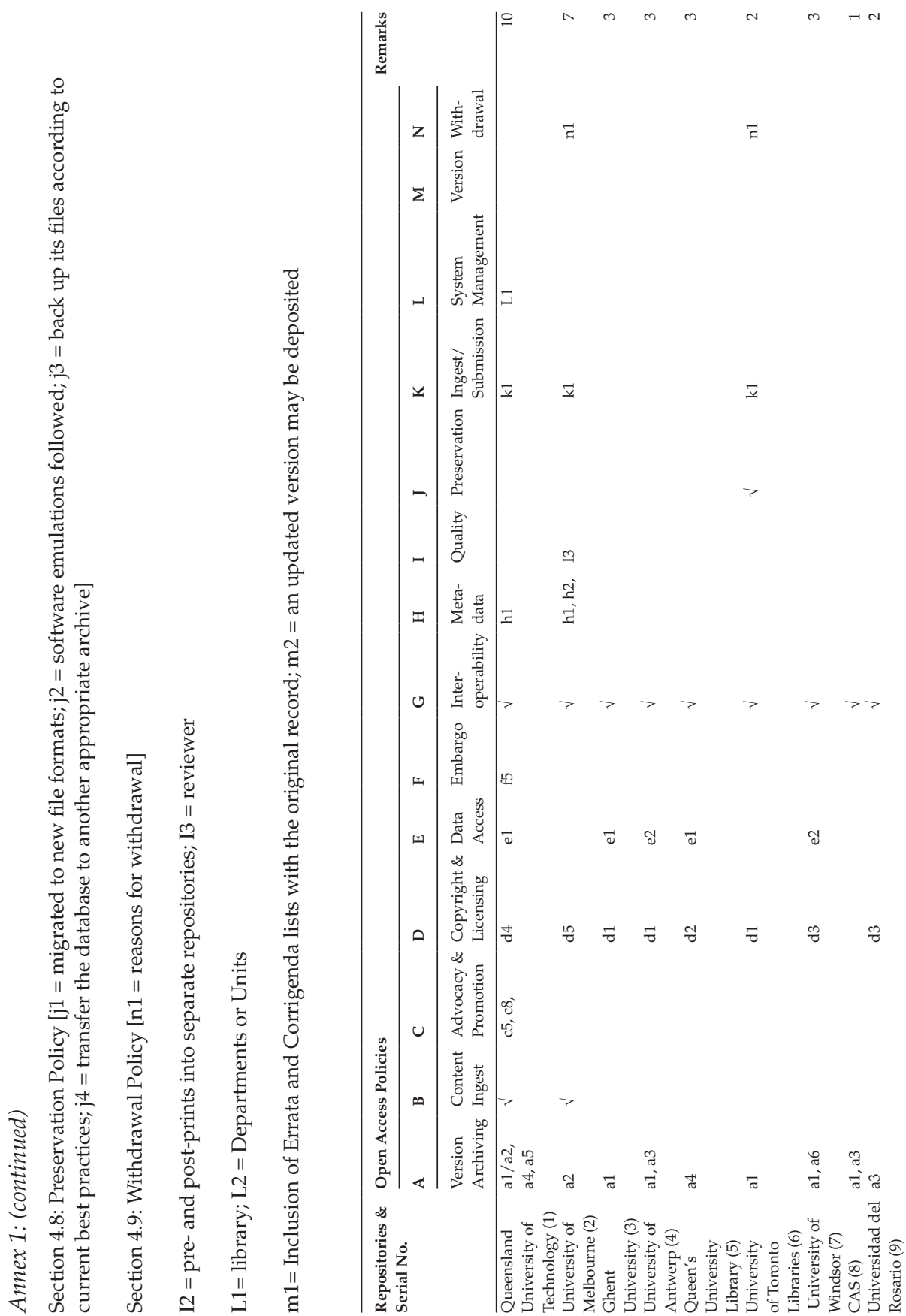
Towards An Open Access Policy Framework: A Case Study of COAR

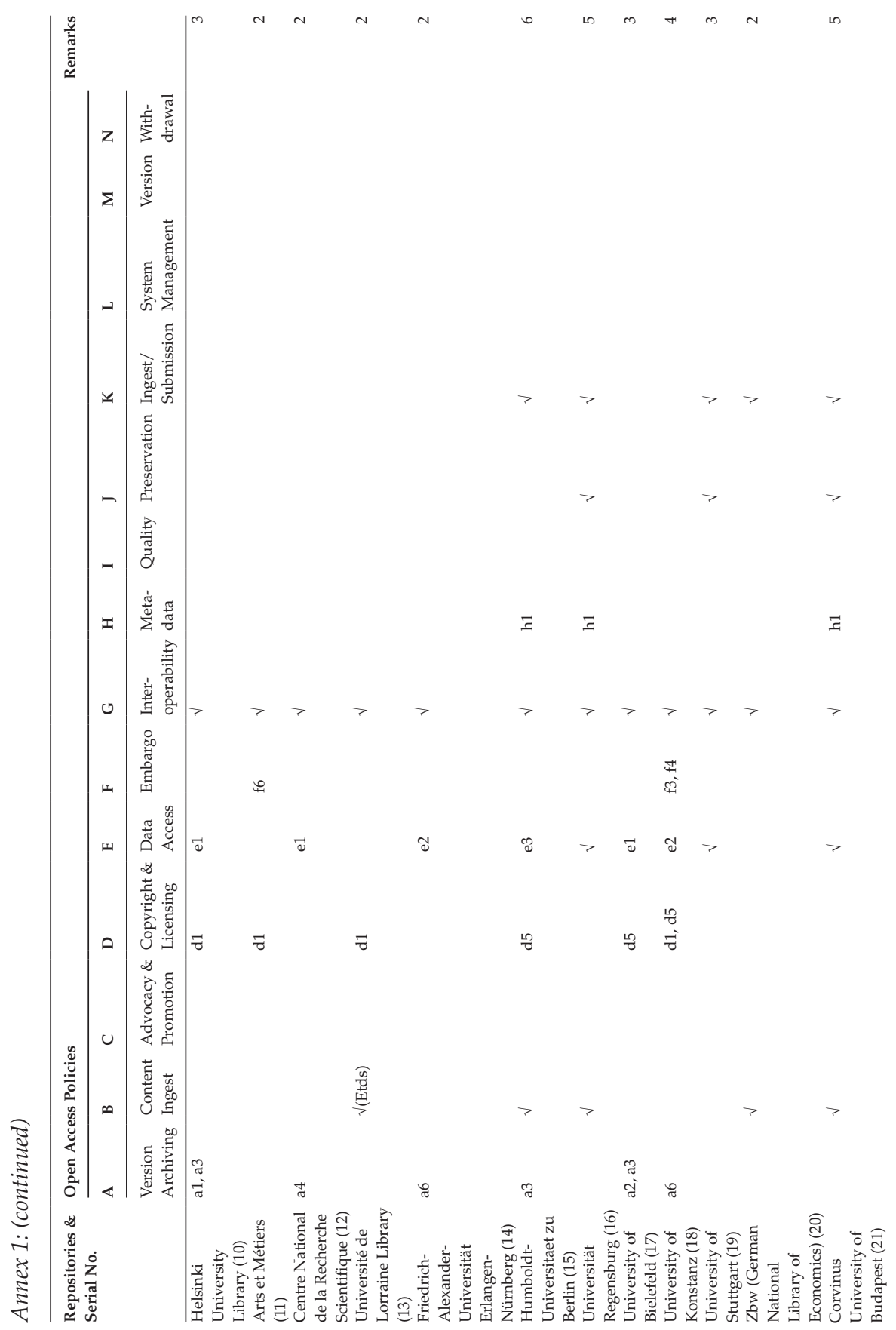


Bijan Kumar Roy et al.

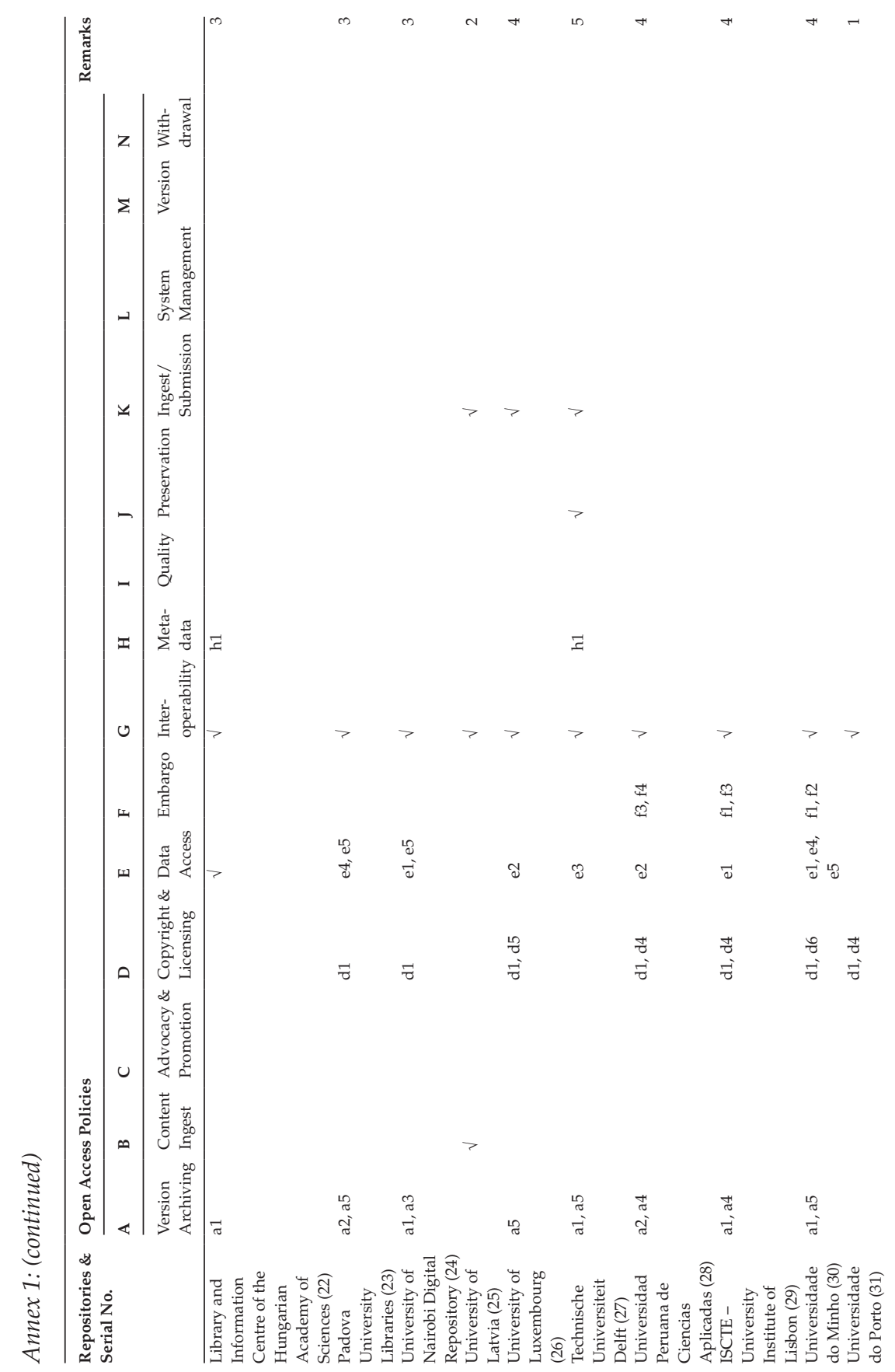


Towards An Open Access Policy Framework: A Case Study of COAR

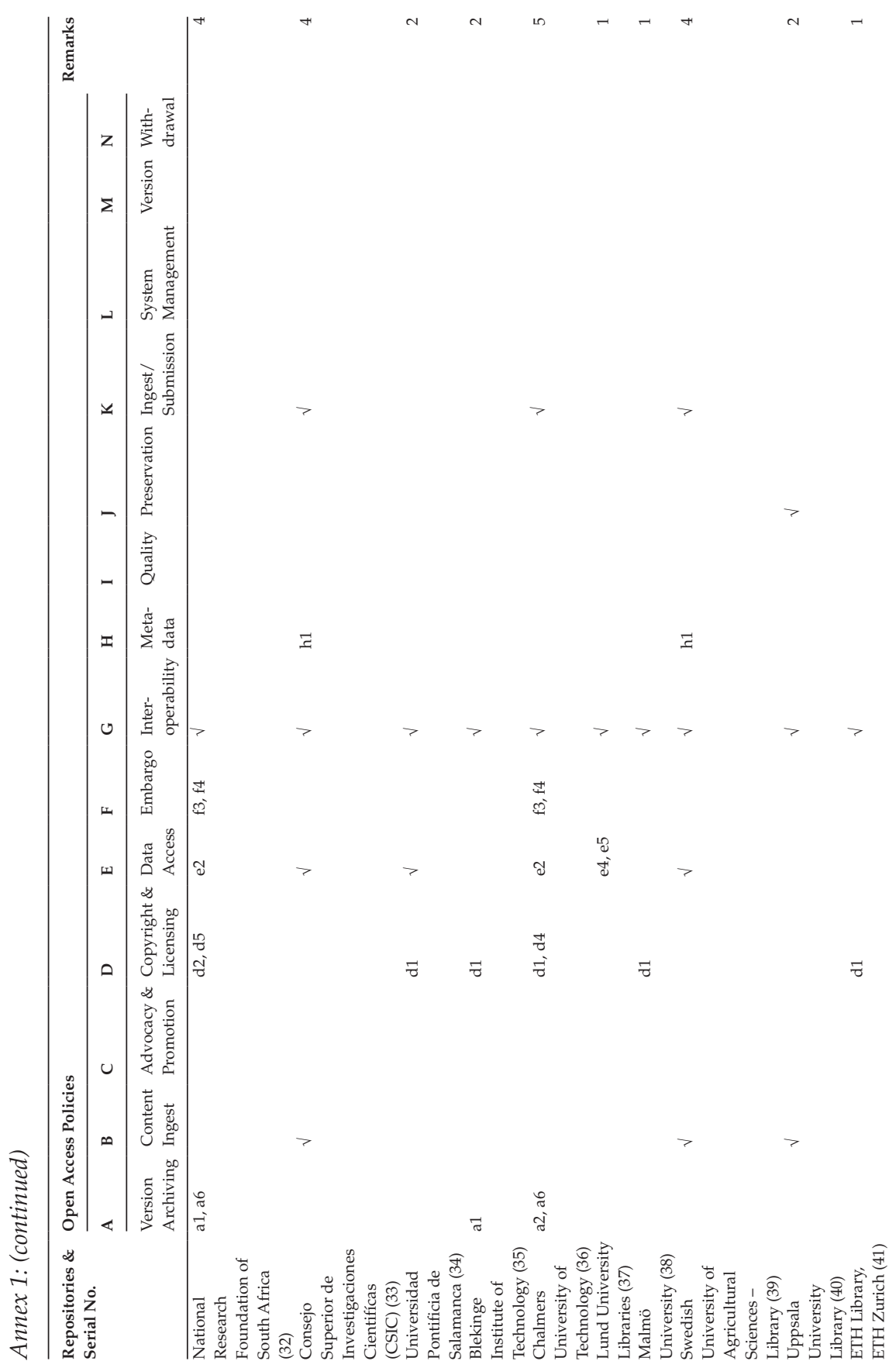


Bijan Kumar Roy et al.

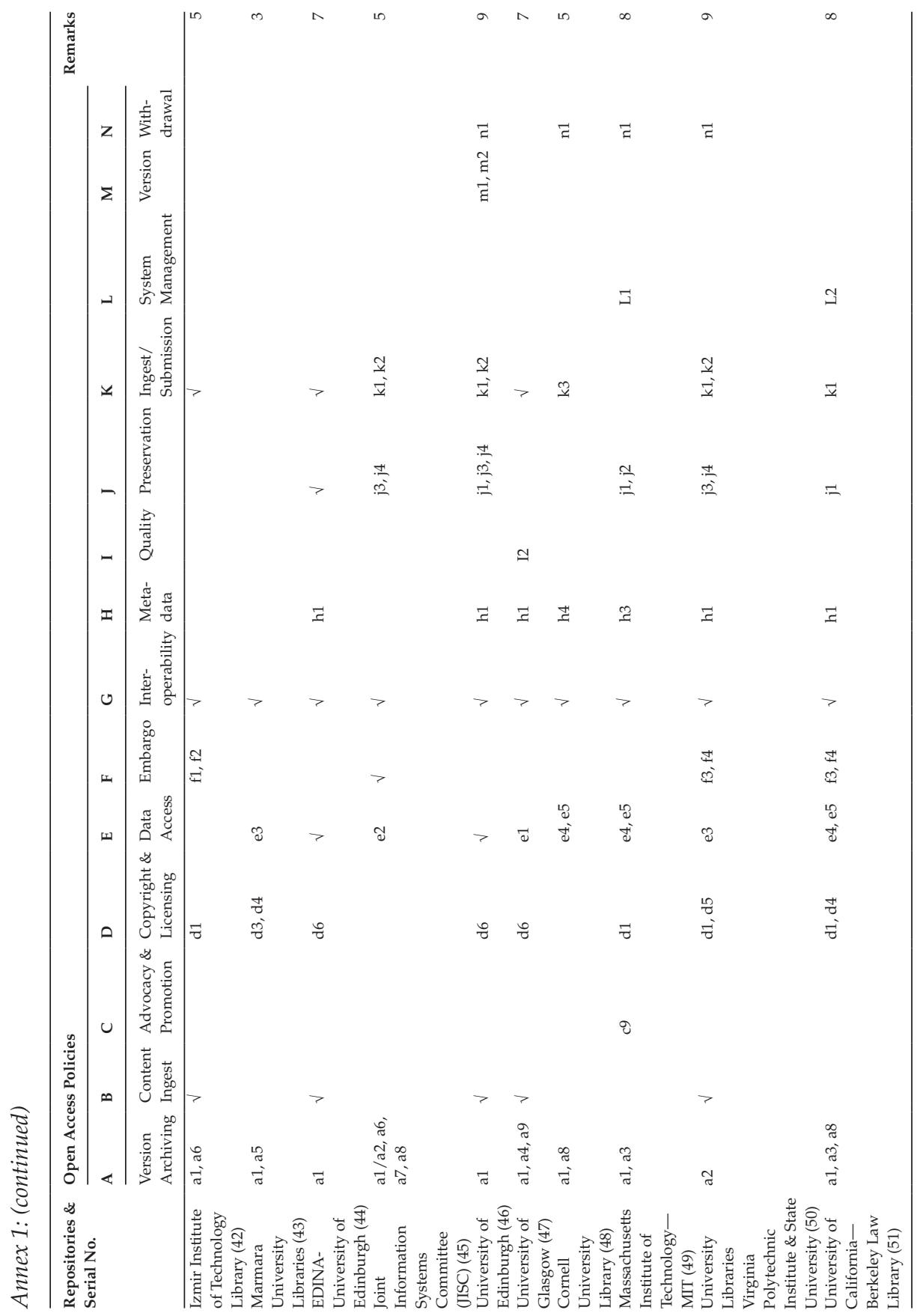

